\title{
Another look at education from a Christian stewardship perspective
}

\author{
Author: \\ Johannes L. van der Walt ${ }^{1}$ \\ Affiliation: \\ ${ }^{1}$ Faculty of Education \\ Sciences, Potchefstroom \\ Campus, North-West \\ University, South Africa \\ Correspondence to: \\ Johannes van der Walt \\ Email: \\ hannesv290@gmail.com \\ Postal address: \\ 18 The Vines, Luneville Road, \\ Lorraine, Port Elizabeth 6070, \\ South Africa

\section{Dates:} \\ Received: 14 Mar. 2012 \\ Accepted: 27 Sept. 2012 \\ Published: 10 Dec. 2012 \\ How to cite this article: \\ Van der Walt, J.L., \\ 2012, 'Another look at \\ education from a Christian \\ stewardship perspective', \\ Koers - Bulletin for Christian \\ Scholarship 77(2), Art. \#428, \\ 7 pages. http://dx.doi. \\ org/10.4102/koers.v77i2.428
}

(C) 2012. The Authors. Licensee: AOSIS OpenJournals. This work is licensed under the Creative Commons Attribution License.
Despite the current postmodern aversion to large-scale philosophies, another look at Christian stewardship education has become necessary. Christian educators need a reminder in the prevailing socio-political conditions in South Africa about the intricacies of their calling and duties towards the upcoming generation. The article commences with a discussion of education in general and then goes on to argue that the 'thin', minimalist and universalist language of modern day secular pedagogical theory should be augmented, or preferably replaced, by the 'thick', maximalist and particularist language of education theory rooted in the Bible. The article highlights a number of key concepts associated with Christian stewardship education and concludes by observing that, whilst an entire book (once again) could have been written on the subject, the discussion of a few key issues with regard to Christian stewardship education can serve as a reminder to Christian educators about their pedagogical responsibilities.

Nog 'n kykie na Christelike rentmeesterskapsopvoeding. Ten spyte van die hedendaagse postmoderne bevraagtekening van grootskaalse filosofieë het nog 'n kykie na Christelike rentmeesterskapsopvoeding in Suid-Afrika noodsaaklik geword. Christelike opvoeders moet in die heersende sosio-politieke omstandighede herinner word aan die ingewikkeldheid van hulle roeping en taak teenoor die opkomende geslag. Die artikel begin met 'n bespreking van opvoeding in die algemeen en daarna word geredeneer dat die 'dun', minimalistiese en universalistiese taalgebruik van hedendaagse sekulêre opvoedingsteorie aangevul, of verkieslik vervang moet word deur die 'dik', maksimalistiese en partikularistiese taal van opvoedingsteorie geanker in die Bybel. Die artikel belig ' $n$ aantal sleutelbegrippe wat met Christelike rentmeesterskapsopvoeding saamhang. Aan die einde word tot die slotsom gekom dat hoewel daar (weer eens) 'n hele boek oor die onderwerp geskryf sou kon word, die bespreking van enkele kernvraagstukke rakende Christelike rentmeesterskapsopvoeding kan dien om Christelike opvoeders aan hulle pedagogiese verantwoordelikhede te herinner.

\section{Introduction and background}

For various reasons, the scholarly discipline known as Philosophy of Education has since the early 1990s all but disappeared from the encyclopaedia of education disciplines in South Africa. ${ }^{1}$ Its gradual loss of popularity in South African teacher education programmes in favour of (new) disciplines such as Citizenship Education, (Social and Theoretical) Foundations of Education, Life Orientation and Critical Theory can arguably be ascribed to the advent of a postmodern attitude in which the value of 'grand narratives' in the form of systematic philosophies of education is questioned (Parkin 2011:156-7; Tripp \& Tripp 2008:15; Col 2:8). Small-scale, personal and critical assessments of conditions prevailing in the world are deemed to be more helpful (see Jansen 2011). Political turmoil, in the form of world-scale economic crises as well as local (South African) transformation, has also been contributing to this state of affairs. Christian educators have furthermore seen since 1994 how neo-liberal and neo-capitalist political conditions have eroded the Christian ethos of school and family education and what inroads influences from public media such as television, newspapers, journals and social communication media (such as sms, Mxit, Facebook, the Internet) have been making on the ethos of child-rearing. According to De Botton (2012:77), we really do not know on which value system we should base our pedagogical interaction with the upcoming generation in these confusing circumstances.

Philosophy of education has also lost ground because all publicly funded tertiary institutions in South Africa have become secularised; they prefer not to officially attach themselves to any religious denomination or ethos (with the exception of the ethos of secular humanism, as has been argued by, amongst others, Van der Walt (2004; 2007:221ff.) and Tripp \& Tripp (2008:15-19). There is nevertheless a need for guidance with respect to the upbringing of Christian children receiving

1.This is fortunately not the case worldwide as can be deduced from the 1519 entries in The Stanford Encyclopedia of Philosophy (key phrase 'philosophy of education') 
their school education in a secular context which has been philosophically determined in South Africa by the Manifesto on Human Rights (Chapter 2, Constitution of the Republic of South Africa; Act 108 of 1996) and further expounded in the Manifesto on Values, Education and Democracy (Ministry of Education 2001).

There is yet another reason for attempting to offer a more or less systematic overview of the main precepts of education from a stewardship perspective. Du Preez and Roux (2010:15, $19,22,23)$ found that the teacher-participants in their study remarked about the discrepancy between values taught at public school and those nurtured at home and in the community. This is why it will remain important to keep informing Christian educators about a Biblical stewardship approach to education.

\section{A note on method}

The Biblical stewardship approach to education has been expounded through the years in a piecemeal manner by philosophers of education, some from a rather fundamentalist orientation that does not appeal to other Christian educators and educationists. This article attempts to describe the contours of the Christian stewardship perspective to education is such a manner that it can be used by Christian educators in societal environments with a Christian ethos as well as by those who ply their profession in secular surroundings such as a South African public school that should, by law, be life-conceptually 'neutral' or based on a human rights ethos as prescribed by the South African Schools Act (Act 84 of 1996).

The following discussion of Christian stewardship education is furthermore based on an approach that can be typified as methodological or exemplary individualism. Because of this and also because of it having been written from a particular life-view perspective based on an interpretivist-constructivist approach to the subject, the discussion cannot be objective. Interpreted knowledge is always a social construction: A thinker constructs his or her own reality, contextualised by a particular time and space. He or she creates subjective meanings as they interact with the world (in this case, the world of stewardship education) (Onwuegbuzie, Johnson \& Collins 2009:120 ff.; Lusenga 2010:35).

\section{The Christian stewardship approach to education}

\section{The essence and structure of education in general}

It is usually understood in the libertarian and postmodern societies in which most Westernised people live today that the state and also individuals should not harbour any expectations to impose measures, including a form of education, that would affect the inner well-being or the outward manners of citizens or other people. Religions, on the other hand, have always had far more directive ambitions, advancing far-reaching ideas about how members of a community should behave towards one another. In contrast to a libertarian-postmodern approach, they do not leave questions about inner well-being and behaviour towards others to the conscience of individuals and to personal morals only. Rather, they expect the (religious) community to embody and, in some cases, even impose desirable conduct on its members, particularly its younger members.

Since neither a libertarian-postmodern approach nor its opposite, a moralistic approach as outlined above, can be condoned from a Christian pedagogical point of view, it is important to depart from a proper understanding of the essence of education or pedagogy in general. More than five decades ago, the Dutch educationst Langeveld (1959) wrote:

It is typical of the educator that his (or her) interaction with and guidance of, his/her protection as well as leading to independence of the educand ${ }^{2}$ (literally: pupil), in brief, his/ her entire pedagogical behaviour, should be aimed at helping the child to come of age (to adulthood, independence, literally: 'mondig worden') and to equip him or her to independently fulfil his or her life-task. (pp. 27-28)

Van Rensburg, Landman and Bodenstein (1994) followed this up by defining education:

... as purposeful guidance that occurs within a normative and juridical framework, and that is characterised by communicative, dignified and non-discriminative actions such as giving support and transfer [of knowledge, skills and morals - author] by brave educators and learners that possess malleable potential. (p. 122)

Most definitions of education therefore embody the following notions: The educator should experience a calling towards attending to the needs of the young and less experienced. The educator should be competent for the task of attending to those pedagogical needs. The educator should practise wisdom in his or her interactions with the younger or less experienced person (the educand). He or she should contrive to make a disciple (follower) of the educand by setting a good moral example that may be voluntarily and freely emulated. He or she should allow the educand to develop and unfold his or her potential and enable him or her to discharge the various commissions of life, including a life-task (Van Dyk 2003:156; Van Dyk 2000:65-66).

As the etymology of the term 'pedagogy' (agein) suggests, education entails the leading or guiding of the educand in a desired direction, in terms of a certain value system, a particular life view and even religious or spiritual commitment. This concept is similarly reflected in the Latin educare, literally translated as 'to bring forth' or to 'lead forth' (Peck 2006:240). Discipling (i.e. making a follower) and disciplining suggests that the educator should take the responsibility for guiding or leading the young person in a direction that the educator herself would find appropriate for her own life and future. Educating people, particularly stewardship education, does not mean to indoctrinate the educand but rather to help him or her to lead a suitable or appropriate life; it is brought forth from his or her unconscious to his or her awareness. The 2.From the Latin future passive participle (masc. sing.) educandus or (fem. sing.) educanda; literally 'which is to be brought up, to be reared'; the person who is being educated. 
educand is not only perceived but also treated (guided, led) as the possessor and the processor of his or her knowledge (Peck 2006:240-241).

Education furthermore embodies sub-structures such as enabling, guiding and equipping the educand (Van Dyk 2003:155-158). The educand must be enabled to meet the requirements of her or his calling or tasks as a future adult. She or he must be equipped with the necessary skills for that calling or task. The educand requires a long period of nurture and, according to Parekh (2000:145), cannot grow into a sane adult without a stable, loving and stimulating environment and a sense of belonging and rootedness. The educand needs to acquire certain basic capabilities and skills in order to hold the self together, to make sense of his or her life (see discussion of the microcosmic map, world and life view below), to establish civil and moral relationships with others, to find his or her way around in the wider society and to take many decisions and reflect on actions (see discussion of the 'examined life' below). Thanks to the unique capacities of each educand, they create a world of meaning and values, thereby not only enriching the world but, most importantly, creating a new world of their own.

\section{Christian stewardship education}

\section{What Christian stewardship means}

Christian stewardship education departs from general definitions of education such as those listed above but purposely fills the various facets of education with content flowing from Biblical perspectives. In doing so, it fills the 'thin' moral and pedagogical language of these definitions with 'thick' moral and pedagogical content (cf. Parekh (2000:128ff.) for the distinction between thick (maximalist, universalist) and thin (minimalist, particularist) moral language and the interplay between them which could arguably result in regulative or pluralist universalism; see Parekh 2000:158; Ramcharan 2008:13; Ackerley 2008:24, 38, where he refers to universalistic aspirations versus contextualised and structured meaning; also Van den Beek 2010:40-42) ${ }^{3}$.

The term 'stewardship' literally means to take care of something entrusted to one, to manage another's estate or property, the charge committed to one. We have been given stewardship over our time, energy, talents, values, feelings, behaviour, money and all other things (Cloud \& Townsend 1992:73). In pedagogical context, children and their upbringing are somehow deemed to have been entrusted to their educators. Christians feel themselves entrusted with this duty by the personal triune God who has revealed himself in the Bible. This conviction is rooted in the Creation or Great Mandate (Gn $1: 28){ }^{4}$

3.The method of filling 'thin' value statements with 'thick' life conceptual meaning should not be confused with the transformation (appropriation, rehabilitation or revision) of secular views which is the last phase of transcendental criticism.

4.For a detailed discussion of the pedagogical meaning of the Great Mandate, refer to Van Brummelen (1994:26-31).

\section{The objective of stewardship education}

The purpose of the nurturing or 'shepherding' (Jones 2006:145) of a child entrusted to an educator is to guide the latter to self-stewardship, to teach him or her to lovingly care for a developing self, to have a sense of 'mine' and 'self' (Cloud \& Townsend 1992:73). Self-stewardship is therefore synonymous with taking self-control. To educate is to help the educand to discover and develop his or her innate potential, in other words, to actualise the self. Coupled with this is the ideal of self-driven development. In this scenario, the educator is a facilitator assisting the educand to develop according to his or her own needs and vision of a future self. Experiential learning plays a key role in this approach: Experience leads to the expansion of areas of knowledge and skills (Loubser 2005:65). The development of self-stewardship must always be contextualised and counterbalanced, however, according to Matthew 22:37-39, by the second half of the Great Commandment, namely to love one's neighbour as oneself. The love of the neighbour arises from the love of God as its Source. Love of the neighbour would include a strong sense of loving and caring for others, with justice for all as one's pedagogical goal.

The objective of the Christian educator is not simply to ensure that the educand does not become a criminal or that he or she 'does well' or leads the good life. Rather, the educator's desire is that the educand should love the Lord his or her God with all soul, heart and mind and love others as he or she would love the self. To achieve this objective, Christian stewardship education should be rooted in Scripture and not in any other source. Christian educators have the divinely appointed task to command God's works to the next generation (Ps 145:4). They have to proclaim God's truth and not secular or their own ideas (Dt 32:46-7). The goal of formative stewardship instruction from a Biblical perspective, according to Tripp and Tripp (2008:37), 'is that we and our children and our grandchildren may fear the Lord and walk in his ways, enjoying a long life'. God designed people, including the educand, to worship. The only question is: What will they worship? If the educand is not guided to learn to worship God, he or she does not cease to worship. They simply worship something other than God (Rm 1:21-23, 25) and in doing so become secularised. According to Tripp and Tripp (2008:95), the heart of the educand then becomes the shrine where idols are worshiped (Eph 5:5; Col 3:5). Since the heart is the well-spring of the educand's life (Pr 4:23), educators should concentrate less on external behaviour and more on preventing a 'straying heart' (Tripp 2005:xi).

\section{The educand is also expected to exercise personal stewardship}

An important point that is frequently overlooked, probably due to one-sided concentration on the stewardship task of the educator, is the fact that the educand has come into this world equipped with special potential and gifts which flow from the human being's special status and dignity as the image of God and for which he or she should exercise responsible stewardship. According to Pratt (1993:2-3), Calvin helped Christians understand who they are in the 
light of who God is. He is the Creator, and people are his creatures. Without viewing themselves in this light, people will never understand what it means to be human. They are the pinnacle of God's creation, and in this capacity, they reveal God more wonderfully than any other creature. For this reason, Pratt avers, people know themselves as they learn of God, and they know God as they learn about themselves. According to Pratt (1993), the most important thing that people can learn about themselves (and by implication that the educand could learn about him- or herself) is that God as:

the divine King (has) ordained that the human race would be his royal image. Put simply, the expression 'image of God' designated human beings as representatives of the supreme King of the universe. (p. 8)

This expression highlights two sides of human existence: people's humility as well as their dignity (Pratt 1993:8). Their humility lies in the fact that they are human, not divine, and their dignity lies in the fact that they have, as Pratt (1993:19) says, 'a wonderful job description: to fill the world with other images of God and to rule over creation as his vice-regents'. 'Dignity' is an aristocratic or hierarchical concept in the sense that it describes a status and only makes sense in relation to what is judged inferior (for example, a stone). People have dignity because they have capacities which non-humans do not have and which people consider so significant as to make them the basis of an appropriate moral practice (Parekh 2000:146-7). A Judaeo-Christian view emphasises the shared fatherhood of God for all people and the fundamental importance of the creation of human beings as members of one family and as individuals of personal worth. In Christianity, Jesus taught the value of all human beings in the sight of God and advocated love as well as charity, healing the sick, feeding the hungry, welcoming the stranger and caring for the oppressed (Ramcharan 2008:15).

Because of the dignity of the educand, the educator should cherish the latter's sense of self-worth, value his or her individual and collective achievements, encourage them to develop and express their human capacities, and help create conditions in which they can lead worthy and meaningful lives (Parekh 2000:148). Based on the concept of human dignity, every individual should enjoy equal opportunity to develop his or her potential (Ramcharan 2008:55).

\section{The educand needs care and guidance}

The educand cannot discharge this responsibility spontaneously or as a matter of course; he or she needs guidance to be able to do so. According to Tripp (2005:xxxxi), shepherding best describes the educator's relationship with the educand. The educator is the educand's guide. Shepherding helps the educand to understand him- or herself and the world in which he or she lives. The educator shepherds the educand to self-assessment. The educator shepherds the educand not only to understand the 'what' of his or her actions but also the 'why'. As shepherd, Tripp maintains, the educator wants to help the educand understand him- or herself as a creature made by and for God. This must be done by leading the educand on a path of instruction. According to Tripp (2005):
The shepherding process is a richer interaction than telling your child what to do and think. It involves investing your life in your child in open and honest communication that unfolds the meaning and purpose of life. It is not direction, but direction in which there is self-disclosure and sharing. Values and spiritual vitality are not simply taught, but caught. ... [Educators] must ... actively shepherd the Godward orientation of [their] children. In all of this, the educator must pray that God will work in and around [his or her] efforts and the responses of [his or her] children to make them people who know and honour God. (pp. $x x i, 25)$

The educand should not only learn to know the Giver of his or her potential and gifts but also how to become accountable with regard to how those gifts are used and unfolded. As Hollick (2006:355) rightly remarked, all people come into this world with an innate sense of stewardship, as evidenced by the question: 'Who am I, and why am I here?' The educand needs instruction as part of the shepherding of his or her heart. The instruction not only informs the mind, it is directed to persuading the heart of the wisdom and the truth of God's ways. Impression of the truth on the heart of the educand, say Tripp and Tripp (2008:15), is not to control or manage him or her, but to point them to the greatest joy and happiness they can experience, namely to delight in God and the goodness of his ways.

Writing from a psychological perspective, Peck (2006:4) draws attention to the importance of spiritual growth for preempting mental illness. Educators have to find the means to ensure mental and spiritual growth in the educand (Fowler 1987):

By this I mean let us teach ourselves and our children the necessity for suffering and the value thereof, the need to face problems directly and to experience the pain involved.

It makes sense for educators to distinguish and individualize between educands because of differences in the quantity and degree of gifts that they each have been endowed with. The educator should acknowledge and respect the place and unique contribution of each educand. Each one of them has something unique to contribute, not necessarily at the intellectual, academic or scientific level expected from them in the school context. The educator is therefore charged with the task of trying to discover what the unique contribution of each educand could be, attach value to it, develop it further and help the educand apply those gifts in the interest of the entire community. (p. 207)

According to a stewardship approach, educators realise that each educand has a separate and unique moral understanding, which at first may be quite unsophisticated but may develop to more mature levels. Whilst therefore refraining from imposing his or her moral standards on ${ }^{5}$ the educand, the educator will facilitate decision-making by opening all the possibilities for the educand and examining all of them with the educand. This approach also applies to the educand's development of a personal life view. The educator never indoctrinates the educand or coerces him or her to adopt certain views but rather guides the educand in the process of developing a life view in terms of which the latter can figure out for herself who she is, what her task

5. Which would be moralistic. 
in life is, how she should learn and master knowledge and to whom she should be accountable and responsible (Edlin 1999:127).

Stewardship furthermore implies taking care of the child and also of his or her education. By nature, human beings take care of things entrusted to them, including property, their bodies, their jobs and income, their spouses and so on. Christian educators take loving care of what has been entrusted to them (in casu the child and its education) because they feel themselves driven by inner motives based on their religious commitment. A steward feels herself or himself committed to the task and therefore experiences a deep sense of responsibility towards the charge-giver. In a play on words, Lategan (2011:87) contends that 'responseability' embodies notions such as the idea that someone or something will not be used for personal gain, that the creation and maintenance of relations will be to the benefit of the other and for the purpose of protecting him or her from harm. Stewardship education furthermore consists of caring, loving, developing, nurturing, maintaining and protecting the child in all respects of his or her personhood. Stewardship is aimed at improving the wellbeing of the other, in this case, the educand.

\section{Stewardship entails making willing followers}

In a Biblical stewardship context, the term 'disciplining' means something altogether different from what it means in a secular situation. In a Biblical context, it refers to the forming or nurturing of disciples. Because of the fact that children have been endowed with potential and entrusted with the task of moral decision-making, pedagogical interaction with them should entail much more than mere teaching and the mastery of learning content. It should also include leading children to understand the surrounding reality and to discover their own place and task therein. They should also be guided, made competent and equipped for fulfilling this task in the world. In view of this perspective, discipline should always form part and parcel of the loving nurturing offered by the educator (Edlin 2004:12). Educands should be guided, equipped, cared for and enabled to respond appropriately to what they perceive to be their calling in life (Fowler, Van Brummelen \& Van Dyk 1990:35; Van Dyk 2003:156; Van Dyk 2000:65-66), and for that, Peck (2006) maintains, discipline is required. Discipline, in his opinion:

is the basic set of tools we require to solve life's problems. [...] these tools are techniques of suffering, means by which we experience the pain of problems in such a way as to work them through and solve them successfully, learning and growing in the process. When we teach ourselves and our children discipline, we are teaching them and ourselves how to suffer and also to grow. (pp. 5-6)

As human beings grow in discipline, love and life experience, their understanding of the world and their place in it naturally grows apace (and vice versa). Education in the form of cultural contact is important for this growth. The educand tends to believe what the people around him or her believe, and he or she tends to accept as truth what these people tell them of the nature of the world as they listen to them during their formative years (Peck 2006:177).
Most importantly, Peck (2006:177-8) argues, stewardship education does not so much depend on what the educand is being told in the context of (for instance) family culture but rather on what the educators do - how they behave toward each other, toward their siblings and other people. It is not so much what the educators say that determines the worldview of the educand as it is the unique world they create for the educand by their behaviour. If an educand has loving, forgiving educators, he or she is likely to believe in a loving and forgiving God. Then, in their adult view, the world will likely seem as nurturing a place as their childhood was. In brief, Peck (2006:179) concludes, the educand's religion and worldview is initially largely determined by their unique childhood experience. To develop a religion and worldview that is realistic, i.e. that conforms to the reality of the cosmos and our role in it, as best we can know that reality, the educand has to be guided and urged to constantly revise and extend his or her understanding to include new knowledge of the larger world. They must constantly enlarge their frame of reference and learn not to operate from a narrow frame of reference, in other words, not to fail to transcend the context of their particular (family, community) culture, their particular set of parents and other educators and their particular childhood experience. They not only have to develop an own new set of worldview assumptions, but they also have to learn to be personally aware of their assumptions (Peck 2006:180). Spiritual growth requires examination of one's existing microcosmic map (worldview), rejecting aspects of it where necessary and replacing them with elements that previously could have been perceived as 'threatening and unfamiliar'. In the final analysis, there is no such thing as a good handme-down religion or worldview. To be vital, to be the best of which one is capable, one's religion and worldview should be a wholly personal one, forged entirely through the fire of one's questioning and doubting in the crucible of one's own experience of reality (Peck 2006:181-2).

Clearly, Peck is here echoing the Socratic dictum that the unexamined life (and world view) is not worth living. One's view of life should be the result of close and critical examination, which may even include a unique confrontation with the (God of the) Bible and with all the hand-me-down beliefs and assumptions that have been passed on by the previous generation. On Peck's account, stewardship education also entails encouraging the educand to live the examined life.

\section{Stewardship implies a serving attitude on the part of the educator}

Whatever the educator contemplates or actually does should attest to the fact that he or she has the interests of the educand at heart. The latter should feel that he or she is being loved, taken care of and catered for. At the same time, though, the latter should learn to accept guidance and follow examples of good conduct, to show respect and to love others with the same caring and loving attitude. Never should the educator apply his or her authority and physical strength to dominate the educand or to force him or her to do what the educator 
wishes. ${ }^{6}$ Whatever power the educator might possess should be employed in the interest of lovingly and caringly promoting the interests of the educand (Edlin 1999:131).

\section{The upshot of stewardship education}

Spiritual, emotional and other forms of growth are the results of good stewardship. We cannot value or treasure ourselves and what belongs to us if we have not been valued and treasured (Cloud \& Townsend 1992:281). Without such care, a person cannot shake off a deep sense of being worthless and unlovable, and without such care, a person is unable to protect, nurture and develop the life that has been entrusted to him or her (Cloud \& Townsend 1992:282, 291). The end goal of Christian stewardship education is to imbue the educand not only with an internal sense of motivation to take up his or her life-task but also to become responsible, emphatic and caring. The educand assumes this attitude not because it is important for the educator but for him- or herself. It is only when love and limits are a genuine part of the educand's life that true maturity can occur (Cloud \& Townsend 1992:199). Obversely, as Schneller (2011:184) observed, an educator can kill the creative instincts of the educand through surveillance, rewards, competition, overcontrol, restricting choice, pressure and time restrictions. To return to the etymology of 'education', educare, to lead forth should be reinterpreted to mean 'to lead forth the hidden wholeness' of the educand. This suggests that educators, as stewards, should be healers who lead their charges to a wholeness of spirit. One expression of the caring attitude of the educator should be his or her willingness to allow the educand to explore his or her abilities, curiosities, talents. As Schneller (2011) insists:

The epitome of care in education is helping students grow, not by imposing the will of society on them ${ }^{7}$, but rather allowing the direction of growth to be determined by what is relevant to the individual student. (p. 187)

\section{The dangers of moralism and individualism}

As mentioned in the methodological note, the foregoing discussion of stewardship might be seen as subjective, individualistic and moralistic because of the focus on the personal stewardship of respectively the educand and of the educator. To see this in the correct perspective, we have to understand that the word 'moralistic' has two meanings, the first of which is unacceptable in a Biblical stewardship context, namely 'trying to regulate the morals of others'. De Botton (2012) applies this meaning in the following quotation:

There is one arena in which we spontaneously favour moralistic intervention over neutrality, an arena which for many of us dominates our practical lives and dwarfs all other concerns in terms of its value: the business of raising our children. [...] Faced with the same two questions which so trouble libertarian theorists in the political sphere - 'Who are you to tell me what to do?' and 'How do you know what is right?' - parents have little

6. Which would, once again, be moralistic behaviour on the part of the educator. The same would apply when the educator tells, attempts to force, coerce or indoctrinate the child in what to do and think.

7.See footnote 6 difficulty at arriving at workable answers; ... [they even] set forth in exhaustive detail the specific behaviours they expect from, and will reward in their children. (p. 74)

The second meaning is more appropriate in a stewardship context, namely to 'live in accordance with moral principles' (Sinclair 1999:959). This explains why, in the discussion above, expressions were used such as educators should follow 'an appropriate moral practice', 'set a good moral example', have been entrusted with the task of facilitating 'appropriate moral decision making' and that each person 'has a unique moral understanding' which should be cultivated.

The second meaning ties in with the problem of individualism. The capabilities approach of Nussbaum (2001) and Sen (2009) was also suspected of being too individualistic in the sense that it did not consider individuals as part of their social environment, as socially embedded and connected to others. It was thought that their approach worked with a notion of atomised individuals (Robeyns 2005:n.p.). To assess the possible critique that the stewardship approach expounded above might have been individualistic, we must distinguish between ethical individualism, ontological individualism and methodological or explanatory individualism. Ethical individualism postulates that individuals, and only individuals, are the units of moral concern. In other words, when evaluating different states of social affairs, we are only interested in the (direct and indirect) effects of those states on individuals. Ontological individualism, on the other hand, states that only individuals and their properties exist and that all social entities and properties can be identified by reducing them to individuals and their properties (Robeyns 2005:n.p.).

Neither of these forms of individualism was ad rem to the discussion of stewardship in the previous section. Claims about personal and individual stewardship were constantly off-set and counter-balanced with claims about social responsibility. There was, for instance, emphasis on the second half of the Great Commandment, the fatherhood of God for all people, individuals as members of the entire human family, the equal worth of all people, the importance of collective achievement, accountability to others for the use of personal gifts, the importance of contributing to the collective, the application of gifts in the interest of the entire community, the avoidance of personal gain at the cost of others, education as a form of cultural and trans-cultural contact, the role of educators and other important persons in the community, and so on.

Methodological or explanatory individualism was used for explaining stewardship education in the previous section. This is the view that something, in this case stewardship education, can be best explained by focusing on individuals and their properties, one of which, as noted above, is that the human being is also a social, communal being (Robeyns 2005:n.p.). A careful reading of the previous section will show that the necessary attention was given throughout to the relations between societal structures and entities, on the one hand, and individuals, on the other hand, as well as to the constraints and opportunities related to these structures 
and entities. The discussion mentions relations and processes that are profoundly social and collective. Individuals are social beings; their existence and properties can therefore not be discussed in isolated terms. The options that a person has in the process of attaining personal stewardship depend greatly on relations with others and how they practise their stewardship mandate towards the individuals in their care.

\section{Concluding remarks}

It has become clear from the research underpinning this article that much more could have been said about the various facets of education, both education in general and, specifically, education from a Biblical stewardship viewpoint. Many subjects have not been touched upon, amongst others the problem of character education, the education of the noble person, the person with integrity, the problem of value education, the role of education in personal and societal development and education that fosters freedom of mind and agency. Many of these aspects of Christian stewardship education had to be left by the wayside in order to concentrate on the key concepts of Christian stewardship education: What it essentially entails, the basic task of the Christian educator as steward, the aims of stewardship education, the forming of religious and life-view commitment, touching and developing the spirit of the educand and the final outcome of this approach if applied effectively. It also became clear that most of the perspectives (values) issuing forth from secular sources are clothed in language which may be typified as universalistic, minimalistic and therefore 'thin' in terms of the values and the pedagogy in question. This article has attempted to clothe all the aspects of education in the particularistic, maximalistic and hence 'thick' value language typical of the Christian stewardship approach to education.

\section{Acknowledgements Competing interests}

The author declares that he has no financial or personal relationships which may have inappropriately influenced him in writing this article.

\section{References}

Ackerley, B., 2008, Universal human rights in a world of difference, Cambridge University Press, Cambridge.

Cloud, H. \& Townsend, J., 1992, Boundaries, Zondervan, Grand Rapids.

De Botton, A., 2012, Religion for atheists, Hamish Hamilton, London.

Du Preez, P. \& Roux, C.D., 2010, 'Human rights values or cultural values: Pursuing values to maintain positive discipline in multicultural schools', South African Journal of Education 30, 13-26.
Edlin, R.J., 1999, The cause of Christian education, National Institute for Christian Education, Blacktown.

Edlin, R.J., 2004, 'Why Christian schools?', in J. Ireland, R.J. Edlin, \& K. Dickens (eds.), Pointing the Way, pp. 1-16, Institute for Christian Education, Blacktown.

Fowler, S., 1987, Christian educational distinctives, IRS, Potchefstroom.

Fowler, S., Van Brummelen, H.W. \& Van Dyk, J., 1990, Christian schooling: Education for freedom, IRS, Potchefstroom.

Hollick, M., 2006, The science of oneness: A worldview for the twenty-first century, $\mathrm{O}$ Books, Winchester.

Jansen, J.D., 2011, We need to talk, Bookstorm, Northcliff.

Jones, T., 2006, Nurturing your child's soul: 10 keys to helping your child grow in faith, W Publishing Group, Washington, DC.

Langeveld, M.J., 1959, Beknopte theoretische paedagogiek, J.B. Wolters, Groningen.

Lategan, L.O.K., 2011, 'Research ethics and integrity: What should be on the agenda?', Journal for Christian Scholarship 47(2), 72-89.

Loubser, C.P., 2005, Environmental education: Some South African perspectives, Van Schaik Publishers, Pretoria.

Lusenga, R.M., 2010, 'School leaders' moral understanding and moral reasoning', PhD dissertation, Faculty of Education, University of Pretoria, Pretoria. (Unpublished)

Ministry of Education, 2001, Manifesto on values, education and democracy, Government Printer, Pretoria.

Nussbaum, M., 2001, Women and human development: The capabilities approach, viewed 14 September 2012, from http:www.books.google.co.za

Onwuegbuzie, A.J., Johnson, R.B. \& Collins, K.M.T., 2009, 'Call for mixed analysis: A philosophical framework for combining qualitative and quantitative approaches', International Journal of Multiple Research Approaches 3(2), 114-139.

Parekh, B., 2000, 'Non-ethnocentric universalism', in T. Dunne \& N.J. Wheeler (eds.), Human rights in global politics, pp. 128-159, Cambridge University Press, Cambridge.

Parkin, J.L. 2011, The ultimate spiritual way, Hay House, London.

Peck, M., 2006, The road less travelled, Random House, London.

Pratt, R.L., 1993, Designed for dignity, P \& R Publishing, Phillipsburg.

Ramcharan, B.G., 2008, Contemporary human rights ideas, Routledge, London.

Robeyns, I., 2005, 'The capabilities approach: A theoretical survey', Journal of development and capabilities 6(1), 93-117, viewed 13 September 2012, from www.tandfonline.com

Schneller, P.L., 2011, 'The creative spirit', in P.L. Schneller \& C.C. Wolhuter (eds.), Navigating the C's: Creativity, Care, Compassion, Character, Cosmopolitanism, Contributionand Critical Awareness: An introduction to comparative education, pp. 169-192, Keurkopie, Noordbrug.

Sen, A., 2009, The idea of justice, Penguin Books, London.

Sinclair, J.M. (ed.), 1999, Collins Concise Dictionary, Glasgow, Collins.

South Africa, 1996, South African Schools Act, Act 84 of 1996, Government Printer, Pretoria.

South Africa, 1996, Constitution of the Republic of South Africa, Act 108 of 1996, Government Printer, Pretoria.

Tripp, T. \& Tripp, M., 2008, Instructing a child's heart, Shepherd Press, Wapwallopen.

Tripp, T., 2005, Shepherding a child's heart, Shepherd Press, Wapwallopen.

Van Brummelen, H., 1994, Steppingstones to curriculum, Alta Vista College Press, Seattle.

Van den Beek, A., 2010, Is God terug?, Meinema, Zoetermeer.

Van der Walt, B.J., 2004, 'Sekularisme, die gees van ons tyd', Tydskrif vir Christelike Wetenskap 40(1/2), 85-98.

Van der Walt, B.J., 2007, Transforming power, Institute for Contemporary Christianity in Africa, Potchefstroom.

Van Dyk, J., 2000, The craft of Christian teaching, Dordt Press, Sioux Center.

Van Dyk, J., 2003, 'The practice of teaching Christianly', in S. Fowler, H.W. Van Brummelen \& J. Van Dyk (eds.), Education for freedom, pp. 155-168, IRS, Potchefstroom.

Van Rensburg, C.J.J., Landman, W.A. \& Bodenstein, H.C.A., 1994, Basiese begrippe in die opvoedkunde, 6th edn., Orion Uitgewers, Halfway House. 